\title{
EFFECT OF ALTERED PHOTOPERIOD ON DELAYED IMPLANTATION AND MOULTING IN ROE DEER
}

\author{
G. A. LINCOLN AND FIONA E. GUINNESS* \\ Unit of Reproductive Biology, University of Liverpool, Life Sciences Building, \\ P.O. Box 147, Liverpool L69 3BX, and *Department of Veterinary Clinical Studies, \\ School of Veterinary Medicine, Madingley Road, Cambridge \\ (Received 26th April 1972, accepted 10th July 1972)
}

The roe deer, Capreolus capreolus, is the only artiodactyle known to exhibit delayed implantation (Short \& Hay, 1966). In Great Britain, mating normally occurs between late July and mid-August and after fertilization development proceeds to the blastocyst stage before growth is arrested (Prell, 1938). Blastocysts remain free in the uterine lumen for about 5 months from August until early January before growth is resumed, implantation occurs and development proceeds normally. The majority of kids are born between mid-May and midJune, and twins are common.

In the roe, the long period of delayed implantation ends in early January very soon after the winter solstice (22nd December) when the days are just beginning to lengthen (Short \& Hay, 1966). The change in photoperiod may, therefore, act as an environmental cue, causing changes in the reproductive system of the doe and resulting in the resumption of embryonic development. This seems probable in the light of experiments with pine martens, Martes americana, and mink, Mustela vison, (Pearson \& Enders, 1944) and more recently with badgers, Meles meles, (Canivenc, Bonnin-Laffargue \& Lajus-Boúe, 1971) in which the duration of delayed implantation was altered by exposing the animals to a modified photoperiod. Alternatively, roe deer may exhibit a fixed period of delay and the date of implantation be normally dictated by the date of conception.

To investigate the importance of photoperiod in this respect, a preliminary experiment was carried out on the Isle of Rhum, Inverness-shire $\left(57^{\circ} \mathrm{N}\right.$, $6.20^{\circ} \mathrm{W}$ ) in $1970-71$. Two yearling roe does were run with a buck from 16 th July until 24th August 1970 and mating with one of the animals was observed on 2nd August. The does were separated from the buck and returned to a grass enclosure ( $\frac{3}{4}$ acre) where they were provided with small amounts of supplementary feed sufficient to maintain their bodily condition. From 9th October until 5th December 1970, the animals were exposed to an artificial light regimen for part of the day by shutting them in a light-proof shed $18 \mathrm{ft}$ long by $8 \mathrm{ft}$ wide. On 9th October, the normal day length from sunrise to sunset was $10 \frac{1}{2} \mathrm{hr}$ and, by enclosing the animals at a particular time each day, the daylight hours experienced by the deer were progressively reduced to $6 \frac{3}{4} \mathrm{hr}$ by $22 \mathrm{nd}$ October, which is the day length normally occurring at the winter solstice in that latitude. Following this, the animals received a progressively increased 
photoperiod for 45 days until 5th December, additional light being supplied by two 200-W electric lights after the animals had been shut inside before sunset. Each evening after receiving the extra light, the deer were released from the shed after dark. After 5 th December, the animals were left outside to receive natural daylight. If delayed implantation ended within a fortnight of the experimentally increased photoperiod, then kidding would occur in April some 2 months early (Text-fig. 1a).

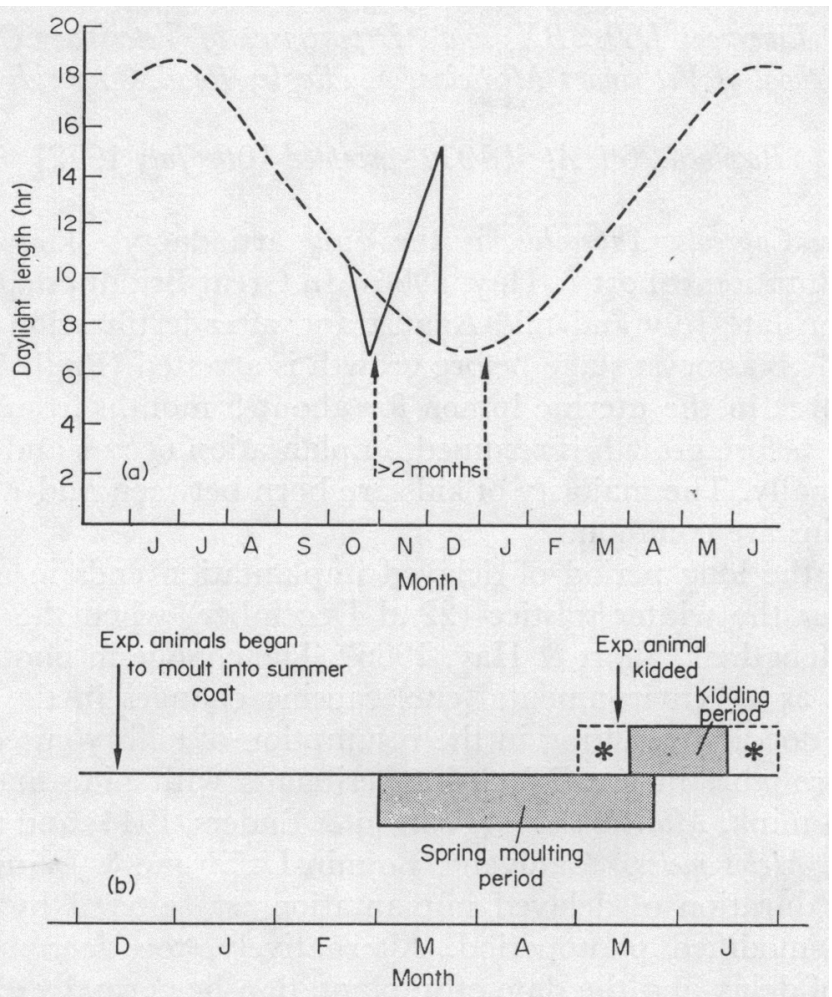

Text-Fig. 1. (a) Normal pattern of daylight length on the Isle of Rhum, Invernessshire (- - ), and the experimental alteration of this pattern used in the present study (solid line). (b) Dates of kidding and moulting seasons of roe deer under normal conditions in Scotland, with arrows indicating these events in the experimental animal that received additional light in the autumn. *, period of very early and very late births in the wild.

Only one of the two does proved to be pregnant and she gave birth on 12th May to twins weighing 1.28 and $1.39 \mathrm{~kg}$. Although earlier than the majority of roe deer births in Scotland (L. MacNally, personal communication), this birth did not indicate that the period of delayed implantation had been significantly reduced and definitely not to the extent of 2 months. However, both animals responded to the altered photoperiod by a change in the pattern of moulting of the winter coat. The first signs of moulting occurred on 11th December 1970, almost exactly 2 months in advance of a similar condition in the same animals the previous year (Table 1). The winter coat was not replaced over the following months as rapidly as expected, and, with some 
periods when moulting appeared to stop, the full summer coat was not fully developed until the normal time in late May.

It is therefore possible to alter the pattern of moulting in the roe deer by modifying the light cycle without significantly affecting the process of delayed implantation. The experimental procedure needs to be repeated with more animals, but the present evidence indicates that the roe doe is not necessarily reliant on the changing pattern of photoperiod to time the date of implantation, and it seems possible that the duration of delayed implantation in the normal state may be partially fixed by some form of endogenous rhythm.

\section{TABLE 1}

DATES AND STAGES OF MOULTING OF THE WINTER COAT SHOWN BY TWO ROE DEER DOES IN THE FIRST 3 YEARS OF LIFE

\begin{tabular}{|c|c|c|c|c|}
\hline $\begin{array}{l}\text { Stage of } \\
\text { moulting winter } \\
\text { coat }\end{array}$ & $\begin{array}{l}\text { First signs } \\
\text { of loose } \\
\text { hair }\end{array}$ & $\begin{array}{l}\text { Red summer coat } \\
\text { coming through under } \\
\text { winter coat and } \\
\text { moulting complete } \\
\text { around eyes }\end{array}$ & $\begin{array}{l}\text { Moulting of win- } \\
\text { ter coat complete } \\
\text { on face }\end{array}$ & $\begin{array}{l}\text { Moulting of } \\
\text { winter coat } \\
\text { complete } \\
\text { over entire } \\
\text { body }\end{array}$ \\
\hline $\begin{array}{l}\text { 1969-70 } \\
\text { (rising } 1 \text { year) }\end{array}$ & $\begin{array}{l}\text { Middle of } \\
\text { February }\end{array}$ & Beginning of April & End of April & End of May \\
\hline $\begin{array}{l}1970-71 \\
\text { (rising } 2 \text { years) } \\
\text { (experimental) }\end{array}$ & $\begin{array}{l}\text { Middle of } \\
\text { December }\end{array}$ & End of January & End of February & $\begin{array}{l}\text { Beginning } \\
\text { of June }\end{array}$ \\
\hline $\begin{array}{l}\text { 1971-72 } \\
\text { (rising } 3 \text { years) }\end{array}$ & $\begin{array}{l}\text { Beginning of } \\
\text { March }\end{array}$ & Beginning of April & & \\
\hline
\end{tabular}

In $1970-71$, the deer were exposed to additional light in the autumn (see text) and the moulting pattern was advanced.

This work was supported by grants from the N.E.R.G. and the Ford Foundation.

\section{REFERENCES}

Canivenc, R., Bonnin-Lafgargue, M. \& Lajus-Boúe, M. (1971) Réalisation expérimentale précoce de l'ovoimplantation chez le blaireau européen (Melis melis L.) pendant la période de latence blastocystaire. C. r. hebd. Séanc. Acad. Sci., Paris, 273, 1855.

Pearson, O. P. \& Enders, R. K. (1944) Duration of pregnancy in certain Mustelids. 7. exp. Zool. 95, 21.

Prell, H. (1938) Die Tragzeit des Rehes. Züchtungskunde, 13, 325.

Short, R. V. \& HAY, M. F. (1966) Delayed implantation in the roe deer, Capreolus capreolus. Symp. zool. Soc. Lond. 15, 173. 